\title{
Usability Testing Menggunakan Model PACMAD Pada Aplikasi Mobile Tabanan Dalam Genggaman
} Usability Testing Use The PACMAD Model On Mobile Application "Tabanan Dalam Genggaman”

\author{
Ni Luh Putu Moni Lestari*1, I Made Ardwi Pradnyana², Gede Aditra Pradnyana ${ }^{3}$ \\ ${ }^{1,2,3}$ Pendidikan Teknik Informatika; Universitas Pendidikan Ganesha \\ 1, 2, 3 Singaraja, Indonesia \\ e-mail: *11 putu.moni.lestari@gmail.com, ${ }^{2}$ ardwi.pradnyana@undiksha.ac.id, \\ 3gede.aditra@undiksha.ac.id
}

\begin{abstract}
Abstrak - Aplikasi Tabanan Dalam Genggaman adalah aplikasi mobile milik Pemerintah Kabupaten Tabanan. Aplikasi ini memuat beragam data dan informasi tentang Kabupaten Tabanan. Sebagai aplikasi yang bersifat public penting untuk melakukan uji guna mengetahui tingkat usability sehingga dapat memaksimalkan kebergunaan aplikasi. Pengujian usability testing menggunakan model PACMAD (People At The Center Of Mobile Application Depelovment) dengan 7 atribut pengukuran serta melibatkan 12 responden pada rentang usia 15-41 tahun. Dari hasil pengujian usability testing yang dilakukan dengan teknik performance measurement, RTA, Kuesioner SUS dan NASA-TLX diketahui bahwa aplikasi tabanan dalam gengaman dapat dikategorikan telah memenuhi tingkat usability yang baik untuk sebuah aplikasi mobile. Hal ini berdasarkan pada terpenuhinya 7 atribut usability pada model PACMAD yaitu efficiency sebesar 0,0380050295 goals/second, effectiveness 97\%, learnability 92\%, memorability 98\%, error 0,090278, satisfaction 59,375 dan cognitive load 43,4444. Sebagai upaya meningkatkan usability pada aplikasi Tabanan Dalam Genggaman maka dirancangan rekomendasi perbaikan dalam bentuk wireframe/mockup yang didasarkan pada teori 8 golden rules dari Benn Sneidermann dan 10 prinsip user interface aplikasi mobile dari Jonathan Stark. Hasil analisis data performance measurement dan data hasil RTA dijadikan sebagai acuan dan pertimbangan untuk memutuskan bagian, halaman dan fitur dalam aplikasi Tabnanan Dalam Genggaman yang akan diberikan rekomendasi perbaikan.
\end{abstract}

\begin{abstract}
Kata kunci-NASA-TLX; PACMAD; SUS; Tabanan Dalam Genggaman; Usability
Abstract - "Tabanan Dalam Genggaman" is a mobile application that belongs to the Government of Tabanan Regency. This application contains various data and information about Tabanan Regency. "Tabanan Dalam Genggaman" as a public application, it is important to conduct a test to determine the level of usability in order to maximize the application's usefulness. Usability testing uses PACMAD (People At The Center of Mobile Application Dept) model with 7 measurement variables and involves 12 respondents from the age range of 15-40 years. From the results of usability testing that were conducted with performance measurement techniques, RTA, SUS Questionnaire and NASA-TLX were known that the "Tabanan Dalam Genggaman" application can be categorized that fulfilled good usability level for a mobile application. It was based on the fulfillment of 7 usability attributes in the PACMAD model, namely efficiency of 0.0380050295 goals/second, effectiveness 97\%, learnability 92\%, memorability 98\%, error 0.090278, satisfaction 59.375 and cognitive load 43.44444. As an effort to improve usability of "Tabanan Dalam Genggaman" application, the recommendation for improvement was designed in the form of wireframe/mockup based on the theory of 8 golden rules suggested by Benn Sneidermann and 10 principles of the mobile application user interface suggested by Stark, J. The results of the analysis of performance measurement data and RTA results were made into RTA as a reference and consideration for deciding the parts, pages and features of the "Tabanan Dalam Genggaman" application that will be given recommendations for improvement.
\end{abstract}

Keywords - NASA-TLX; PACMAD; SUS; Tabanan Dalam Genggaman; Usability

\section{PENDAhuluaN}

Teknologi khususnya teknologi informasi dan komunikasi di era digital saat ini terus mengalami perkembangan dan kemajuan menjadi semakin canggih. Ruang dan waktu bukan lagi menjadi penghalang untuk mendapatkan data dan informasi yang kita butuhkan. Hal ini membuat pelayanan informasi yang cepat, tepat dan akurat sebagai sesuatu yang mutlak untuk dipenuhi oleh pihakpihak terkait yang memangku kepentingan. Salah satunya adalah pemerintahan dan birokrasi sebagai bidang yang sangat potensial dalam pemanfaatan teknologi demi memudahkan dan mengoptimalkan pekerjaannya.

Tabanan adalah kabupaten yang termasuk kedalam wilayah Provinsi Bali, Indonesia. 
Pemerintah Kabupaten Tabanan melalui Dinas Komunikasi Dan Informatika (Diskominfo) secara bertahap telah melakukan perbaikan dan pembaharuan infrastrukstur dasar juga mengembangkan aplikasi-aplikasi inovatif yang memiliki kebermanfaatan untuk meningkatkan efektifitas dan efisiensi kerja diwilayahnya. Salah satu aplikasi inovatif yang sekiranya dapat membawa banyak dampak positif yang meluas dan diklaim dapat mendukung terwujudnya smart city di Kabupaten Tabanan adalah aplikasi mobile Tabanan Dalam Genggaman.

Namun belum lama aplikasi ini rilis, Pemerintah Kabupaten Tabanan sudah menerima banyak respon dari pengguna baik itu keluhan maupun saran untuk perbaikan aplikasi kedepannya. Kritik atau saran tersebut seperti aplikasi yang belum optimal, data dalam aplikasi masih kurang, tampilan aplikasi yang masih kurang bagus, dan aplikasi perlu dikembangkan lagi. Hal ini peneliti ketahui setelah melakukan wawancara dengan I Gusti Putu Winiantara, S.Sos dari pihak Kominfo Tabanan

Berdasarkan wawancara dengan admin aplikasi Tabanan Dalam Genggaman ada indikasi bahwa pengguna kebingungan dalam menggunakan aplikasi. Hal ini terlihat dari sering terjadinya kekeliruan pengguna dalam menginputkan data ke aplikasi. Selain itu diketahui bahwa hingga saat ini belum ada evaluasi dari tingkat usability yang dilakukan terhadap aplikasi Tabanan Dalam Genggaman ini sehingga belum diketahui apakah aplikasi ini telah mencapai tujuannya, mendapat penerimaan yang baik dari pengguna dan memenuhi aspek-aspek usability.

Melakukan usability testing terhadap aplikasi itu penting karena aspek usability merupakan kunci keberhasilan aplikasi dan syarat penerimaan pengguna terhadap aplikasi smartphone.[1] Jika sebuah aplikasi gagal menunjukan dengan jelas apa yang pengguna cari atau inginkan dari aplikasi, maka pengguna akan meninggalkan aplikasi tersebut dan memilih untuk tidak menggunakannya kembali.[2]

Pada penelitian yang berjudul Usability $O f$ Mobile Applications : Literature review and rationale for a new usability model yang dilakukan oleh Harisson et al. pada tahun 2013 menyebutkan bahwa perangkat mobile memerlukan model usability khusus.
Pengembangan konsep PACMAD (People At The Center of Mobile Application Development). Model PACMAD bertujuan memperluas model usability yang ada, seperti Nielsen atau ISO, ke dalam konteks aplikasi mobile. Dengan adanya penambahan atribut cognitive load sebagai kontribusi penting dari model ini. Model ini memiliki tujuh aspek pengujian. Aspek efficiency, effectiveness, learnability, memorability, error, cognitive load dan satisfaction.[3]

Penelitian lainnya yang berjudul Usability Testing of Fitness Mobile Apllication : Methodology and quantitative result di Saudi Arabia oleh Alturki dan Gay pada tahun 2017. Penelitian ini dilatarbelakangi oleh aplikasi mobile yang telah didownload sekitar $25 \%$ nya tidak pernah digunakan lagi, penyebab utamanya adalah rendahnya usability dari aplikasi mobile tersebut. Model usability yang digunakan adalah model PACMAD dengan 7 atribut yang diuji. Metrics usability digunakan untuk mengukur aspek effectivitas, efficiency, learnability, memorability, dan error. Sedangkan cognitive load diukur dengan menggunakan NASA-TLX. [12]

Selanjutnya penelitian lainnya yang berjudul Usability Testing Pada Aplikasi Hooki Arisan Dengan Model PACMAD Menggunakan Pendekatan GQM yang dilakukan oleh Rizawanti et al. pada tahun 2019. Periode retensi pengguna untuk aplikasi mobile sangat rendah, hanya sekitar $10 \%$ pengguna yang ditemukan masih menggunakan aplikasi mobile yang sama setelah enam bulan pengunduhan. Model yang digunakan adalah model usability PACMAD. Metode usability testing yang digunakan adalah Performance Measurement, Retrospective Think Aloud (RTA), dan Kuesioner CSUQ. [18]

Sehingga peneliti akan menguji enam aspek (efficiency, effectiveness, learnability, memorability, error, cognitive load) dengan teknik performance measurement. Khusus untuk aspek cognitive load akan dilakukan pengujian berdasarkan performa dengan teknik performance measurement dan juga akan dilakukan pengujian secara subjektif dengan menggunakan kuesioner NASA-TLX. Terakhir aspek satisfaction terkait dengan tingkat kesenangan dan kepuasan pengguna saat menggunakan aplikasi. Aspek ini akan diuji menggunakan kuesioner SUS (System Usability Scale) yang dikombinasikan dengan teknik RTA (Retrospective Think Aloud). 
Berdasarkan hal-hal yang telah dipaparkan diatas, peneliti berminat untuk melakukan penelitian yang berjudul "USABILITY TESTING MENGGUNAKAN MODEL PACMAD PADA APLIKASI TABANAN DALAM GENGGAMAN" yang bertujuan untuk mengetahui hasil usability testing dari aplikasi Tabanan Dalam Genggaman berdasarkan pada aspek usability dengan atribut-atribut pengujiannya yaitu efficiency, effectiveness, learnability, memorability, error, satisfaction dan cognitive load serta dapat memberikan rekomendasi perbaikan terhadap aplikasi berdasarkan pada hasil usability testing yang telah dilakukan.

\section{LANDASAN TEORI}

\section{A. Aplikasi Tabanan Dalam Genggaman}

Aplikasi Tabanan Dalam Genggaman adalah aplikasi mobile milik Pemerintah Kabupaten Tabanan. Aplikasi ini memuat beragam data dan informasi tentang Kabupaten Tabanan. Pengguna aplikasi juga dapat berkontribusi langsung dan memberikan feed back ke aplikasi seperti memberikan ulasan/review terhadap konten-konten yang ada dalam aplikasi, pengguna aplikasi juga dapat menginputkan secara langsung data mengenai bisnis ataupun usaha yang dimiliki kemudian akan ditampilkan melalui aplikasi sehingga sekaligus aplikasi ini sebagai media promosi yang membantu pengguna untuk mempromosikan usaha atau bisnis miliknya.

Aplikasi ini bersifat publik dan ditujukan kepada masyarakat Tabanan maupun masyarakat umum yang memiliki kepentingan dengan Tabanan.

\section{B. Usability testing}

Usability secara singkat dapat diartikan sebagai kebergunaan. Pengukuran usability dengan metode testing ini dilakukan dengan mengobservasi pengguna saat menggunakan sistem. Pengumpulan dan analisis terhadap data yang didapatkan dari hasil observasi dapat digunakan untuk mengidentifikasi masalah usability.[4]

Selama pengujian berlangsung pengguna akan diminta untuk melakukan interaksi dengan sistem dengan diberikan sejumlah task/ tugas yang harus dikerjakan sementara peneliti mengamati, mendengar maupun mencatat halhal yang dilakukan pengguna selama berinteraksi dengan sistem. Sehingga nantinya dapat terkumpul data kualitatif dan kuantitatif dan menentukan kepuasan pengguna terhadap produk. [5]

\section{Retrospective Think Aloud (RTA)}

Implementasi dari teknik ini adalah dengan meminta responden untuk dapat meverbalisasikan pikiran, perasaan, dan pendapat saat berinteraksi dengan sistem. Hal ini berguna untuk menangkap kegiatan kognitif yang dilakukan oleh responden.[4] Dengan teknik ini peneliti akan lebih mudah untuk memahami bagaimana responden saat melakukan interaksi dengan sistem. Apakah yang dipikirkan dan diharapkan oleh responden saat menggunakan sistem untuk mencapai tujuan tertentu sesuai dengan apa yang dia temukan dalam sistem. Jika responden merasa ada yang salah, tidak sesuai atau terlalu rumit maka hal itu dapat dijadikan sebagai bahan pertimbangan untuk rekomdasi perbaikan terhadap sistem.

\section{Performance Measurement}

Dengan menggunakan teknik ini akan mampu menghasilkan data kuantitatif berkaitan dengan kinerja responden ketika mereka melakukan tugas selama pengujian usability. Adanya interaksi antara peneliti dengan responden dilarang dalam teknik ini. Karena akan berpengaruh pada data kinerja kuantitatif yang dihasilkan dari pengujian. Pengujian teknik ini sebaiknya dilakukan di laboratorium untuk meminimalisir gangguan yang tak terduga sehingga data yang didapat juga akurat.[4]

Data kuantitatif yang dihasilkan dengan teknik ini sangat berguna dalam melakukan pengujian perbandingan waktu pengerjaan untuk melihat efisiensi dan membandingkan jumlah error untuk melihat efektifitas.

\section{E. Usability Model PACMAD}

Model-model usability yang ada saat ini belum mempertimbangkan faktor mobilitas pada perangkat mobile beserta konsekuensinya. Sebuah perangkat mobile memerlukan sebuah model usability khusus yang sesuai dengan konteks apikasi mobile.

Model usability PACMAD menggabungkan atribut standar ISO dengan model Nielsen dan memperkenalkan atribut penting dari aplikasi mobile yaitu cognitive load. Fungsionalitas aplikasi model PACMAD juga mengidentifikasi tiga faktor yang 
mempengaruhi aplikasi mobile pada aspek usability yakni : User, Task dan Context Of Use. Model PACMAD bertujuan memperluas model usability yang ada seperti model Nielsen atau ISO kedalam konteks aplikasi mobile. [3]

Untuk mengetahui perbandingan model usability PACMAD dengan model sebelumnya dapat dilihat pada tabel dibawah ini :

Tabel. 1 Perbandingan usability model

\begin{tabular}{|c|c|c|c|c|c|}
\hline \multirow[t]{2}{*}{ No } & \multicolumn{2}{|c|}{ Usability Model } & \multicolumn{3}{|c|}{ Perbandingan } \\
\hline & Faktor & Aspek & ISO & Nielsen & PACMAD \\
\hline 1 & User & Effectiveness & $\sqrt{ }$ & & $\sqrt{ }$ \\
\hline 2 & & Efficiency & $\sqrt{ }$ & $\sqrt{ }$ & $\sqrt{ }$ \\
\hline 3 & Task & Satisfaction & $\sqrt{ }$ & $\sqrt{ }$ & $\sqrt{ }$ \\
\hline 4 & & Learnability & & $\sqrt{ }$ & $\sqrt{ }$ \\
\hline 5 & Context & Memorability & & $\sqrt{ }$ & $\sqrt{ }$ \\
\hline 6 & Of Use & Error & & $\sqrt{ }$ & $\sqrt{ }$ \\
\hline 7 & & $\begin{array}{l}\text { Cognitive } \\
\text { Load }\end{array}$ & & & $\sqrt{ }$ \\
\hline
\end{tabular}

Aplikasi mobile biasanya digunakan sambil melakukan aktifitas lain sehingga penting untuk mempertimbangkan dampak penggunaan aplikasi mobile dalam konteks yang sesuai. Atribut usability model PACMAD mengidentifikasi 7 aspek usability suatu aplikasi : Effectiveness, Efficiency, Satisfaction, Learnability, Memorability, Error, Cognitive Load. Masing-masing atribut ini memiliki dampak pada aspek usability suatu aplikasi dan karena itu dapat digunakan untuk membantu menilai kegunaan aplikasi.

Oleh karena itu dampak penggunaan aplikasi mobile harus diturunkan seminimal mungkin dengan memperhitungkan cognitive load sebagai kontribusi utama model PACMAD untuk evaluasi usability.[6]

Pengukuran cognitive load dapat dilakukan secara kolektif. Cognitive load dapat diukur melalui 3 pengukuran yaitu : 1. Pengukuran subjektif; 2. Pengukuran berdasarkan tugas dan performa; 3.Pengukuran fisiologis.[7]

\section{F. Task Skenario}

Task skenario adalah skenario tugas yang berisi sejumlah tugas yang harus dilakukan oleh responden saat berinteraksi dengan sistem dengan sistem yang akan diuji usabilitynya. [8]

Task skenario ini harus disiapkan oleh peneliti sebelum pengujian dilakukan. Saat responden mengerjakan task skenario tersebut, peneliti akan mengobservasi dan mengamati bagaimana perilaku responden dalam menggunakan aplikasi tersebut. Dalam pengujian usability cara yang paling efektif untuk memahami suatu sistem apakah suatu sistem atau user interface bisa digunakan dengan baik atau tidak adalah dengan melihat bagaimana orang lain menggunakannya.[9]

\section{G. Kuesioner SUS (System Usability Scale)}

Kuesioner System Usability Scale (SUS) merupakan salah satu jenis kuesioner usability yang sering digunakan dalam usability testing.

Menurut Sorflaten SUS merupakan kuesioner untuk mengevaluasi sistem dari sudut pandang pengguna atau mengukur kepuasan pengguna dalam menggunakan sebuah sistem, SUS juga dikenal sebagai pengukuran kepuasan pengguna yang quick and dirty yang artinya pengumpulan data yang cepat dan data yang dihasilkan dapat dipercaya.[10]

Menurut Tullis dan Stetson (2004) menunjukkan bahwa menggunakan SUS memungkinkan peneliti untuk mendapatkan ukuran dari kegunaan yang dirasakan dari suatu sistem dengan sampel kecil (misalnya, 8-12 pengguna) dan cukup yakin bahwa telah didapatkan penilaian yang baik tentang bagaimana orang melihat sistem atau produk yang diuji.[11]

Berdasarkan skor akhir SUS tersebut akan bisa diketahui seberapa tinggi tingkat usability dan akseptabilitas (acceptable) desain sistem aplikasi yang dikembangkan. Berikut adalah rentang nilai penilaian terhadap skor akhir SUS.

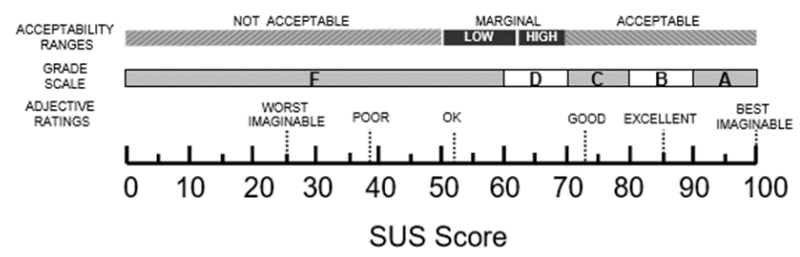

Gambar. 1 Range SUS Score

(Sumber : Bangor et al., 2009: Hal.121)

\section{H. Kuesioner NASA-TLX}

Beban kognitif mengacu pada jumlah proses kognitif yang diperlukan oleh pengguna untuk menggunakan aplikasi. Kuesioner NASA-TLX dapat digunakan sebagai alat penilaian beban kerja subyektif untuk mengukur beban kerja kognitif yang ditempatkan pada pengguna dengan menggunakan suatu sistem.[3]

Untuk menentukan beban kognitif aplikasi, dapat digunakan tes Tugas Beban (NASA) National Aeronatic and Space Administration (TLX) Task Load Index. NASA-TLX memungkinkan peneliti untuk dapat mengevaluasi situasi beban kerja yang dialami oleh pengguna setelah berinteraksi dengan 
sistem yang diuji. Kuesioner ini mengukur tuntutan tugas secara keseluruhan dengan mengidentifikasi 3 skala luas, yang terkait dengan tugas, perilaku dan subjek.[12]
III. METODE

\section{A. Prosedur Penelitian}

Pada Gambar.2 adalah prosedur pengujian usability testing menggunakan model PACMAD pada Aplikasi Tabanan Dalam Genggaman.

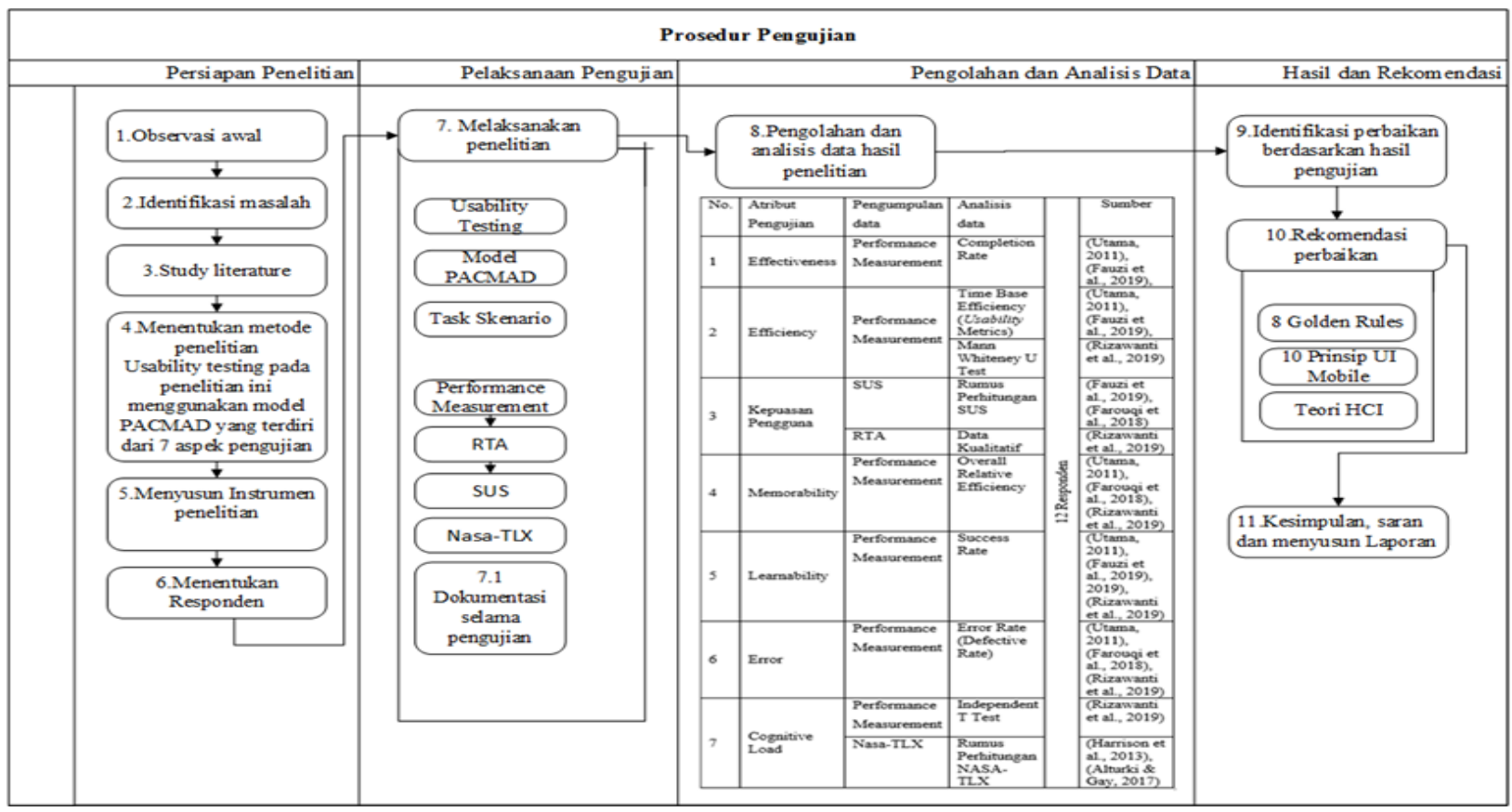

Gambar. 2 Prosedur Penelitian

\section{B. Populasi dan Sample Penelitian}

1. Populasi dan Sample

Populasi yang peneliti gunakan adalah seluruh pengguna yang berpotensi untuk menggunakan aplikasi Tabanan Dalam Genggaman dengan rentang usia 15-44 tahun yang tinggal ataupun memiliki kepentingan di Kabupaten Tabanan.

Dalam usability testing jumlah sample yang digunakan cukup beragam dan tidak ada ukuran pasti harus menggunakan berapa responden sebagai sample dalam penelitian. "The best results come from testing no more than 5 users and running as many small tests as you can afford". Dapat diartikan bahwa hasil terbaik sebuah pengujian berasal dari tidak lebih dari 5 pengguna dan menjalankan test kecil sebanyak yang anda mampu. Menggunakan terlalu banyak responden akan mendapatkan hasil yang tidak jauh berbeda dan hanya mengulang permasalahan yang ada.[14]

Dalam sebuah penelitian yang berjudul "Exploring Inexperienced User Performance Of A Mobile Tablet Application Through Usability Testing" menggunakan sebanyak 12 partisipan pada rentang usia 18-79 tahun.[15] Sehingga dalam penelitian yang akan peneliti lakukan menargetkan sebanyak 12 sample yang dibedakan menjadi 2 jenis yaitu responden mahir dan responden pemula.

\section{Teknik Pengumpulan Data}

1. Observasi

Observasi dilakukan dengan mengamati lingkungan dan kondisi dinas tempat melakukan penelitian. Mengamati lingkungan kerja admin aplikasi. Serta mengamati dan menggunakan aplikasi secara langsung. Sehingga dari hasil observasi dapat didentifikasi dan dianalisis masalah-masalah yang ada dalam aplikasi.

2. Wawancara

Wawancara dilakukan dengan kepala bidang yang bertanggung jawab atas aplikasi Tabanan Dalam Genggaman sehingga didapatkan informasi serta masalah atau kendala yang terdapat dalam aplikasi tersebut secara lebih lengkap.

\section{Teknik Perfomance Measurement}

Teknik ini akan digunakan untuk mengukur 6 dari 7 aspek usability yang diuji yaitu effectiveness, efficiency, error, memorability, learnability, dan cognitive load. 
Selama pengujian berlangsung segala aktivitas interaksi yang dilakukan oleh responden dengan aplikasi akan direkam. Hal ini untuk memudahkan peneliti dalam mengidentifikasi hal-hal yang perlu dinilai selama pengujian dikarenakan teknik ini melarang peneliti untuk berinteraksi dengan responden selama proses pengujian berlangsung.

\section{Restropective Think Aloud (RTA)}

Teknik ini digunakan setelah responden selesai mengerjakan task scenario. Peneliti akan memberikan kesempatan pada responden untuk memverbalisasi pikiran dan perasaannya selama berinteraksi dengan sistem. Jika perlu peneliti akan memberikan stimulus baik berupa pertanyaan dan juga memutarkan video yang telah terekam selama proses pengujian berlangsung. Hal ini dimaksudkan agar responden dapat memverbalisasi pikiran dan perasaan yang dialaminya selama menggunkan aplikasi dengan baik.

5. Kuesioner

Pemberian kuesioner pada penelitian ini dilakukan setelah pengujian usability selesai dilakukan atau sebagai post-test questionaire. Ada beberapa kuesioner usability yang peneliti gunakan yaitu kuesioner SUS untuk mengukur aspek kepuasan pengguna (satisfaction) dan Kuesioner NASA-TLX untuk mengukur beban kognitif pengguna ketika menggunakan aplikasi.

\section{Teknik Pengukuran dan Analisis Data}

- Data Kuantitatif

Pengumpulan data kuantitatif dilakukan dengan usability testing teknik performance measurement, kuesioner SUS, dan kuesioner NASA-TLX kepada responden

\section{Performance Measurement}

Berikut adalah penjabaran pengukuran dan analisis data dari masing-masing aspek tersebut :

\section{a. Effectiveness}

Efektiveness terkait dengan kemampuan pengguna untuk mencapai tujuan mereka dalam konteks yang spesifik. Pada aspek efektivitas dihitung berdasarkan jumlah task yang berhasil diselesaikan (Completion Rate).

Effectiveness=

$\frac{\text { Number of task completed succesfully }}{\text { Total number of task undertaken }} \times 100 \%$

Rata-rata penyelesaian tugas minimum pada pengujian usability adalah $78 \%$, namun bila hasil dibawah $49 \%$ menempatkan pada kuartil bawah.[16]

\section{b. Efficiency}

Efisiensi berkaitan dengan kemampuan pengguna untuk mencapai tujuan berdasarkan kecepatan dan akurasi. Dalam perhitungan dan analisis data effisiensi menggunakan 2 cara. Pertama data diolah menggunakan software SPSS dengan uji statistik non-parametrik Mann Whiteney U Test. Kedua dengan menggunakan rumus Time Based Efficiency.

Time Based Efficiency $=\frac{\sum_{j=1}^{R} \sum_{i=1}^{N} \frac{n_{i j}}{t_{i j}}}{N R}$

Dimana :

$\mathrm{N}=$ Jumlah total tugas

$\mathrm{R}=$ Jumlah pengguna

$n i j=$ Hasil tugas $\mathrm{i}$ oleh pengguna $\mathrm{j}$. jika pengguna berhasil menyelesaikan tugas maka nilainya 1 jika tidak 0 .

tij = waktu yang dihabiskan oleh pengguna $\mathrm{j}$ untuk menyelesaikan tugas i jika tidak berhasil diselesaikan, maka waktu diukur hingga saat pengguna berhenti dari tugas

\section{c. Memorability}

Memorability berkaitan dengan kemampuan pengguna dalam menguasai penggunaan aplikasi secara efektif. Memorability dapat dihitung dari kombinasi nilai effectiveness dan overall relative efficiency.[17] Overall relative efficiency menggunakan rasio waktu yang diambil oleh pengguna yang berhasil menyelesaikan tugas dalam kaitannya dengan total waktu yang diambil oleh semua pengguna.[16]

$$
\text { Overall Relative Efficiency }=\frac{\sum_{j=1}^{R} \sum_{i=1}^{N} n_{i j} t_{i j}}{\sum_{j=1}^{R} \sum_{i=1}^{N} t_{i j}} \times 100 \%
$$

Dimana :

$\mathrm{N}=$ Jumlah total tugas

$\mathrm{R}=$ Jumlah pengguna

nij = Hasil tugas i oleh pengguna $\mathrm{j}$. jika pengguna berhasil menyelesaikan tugas maka nilainya 1 jika tidak 0 .

tij = waktu yang dihabiskan oleh pengguna $\mathrm{j}$ untuk menyelesaikan tugas i jika tidak berhasil diselesaikan, maka waktu diukur hingga saat pengguna berhenti dari tugas.

\section{d. Learnability}

Learnability terkait dengan kemampuan pengguna dalam memperoleh keahlian untuk menggunakan aplikasi mobile. Komponen 
learnability dihitung dengan menggunakan perhitungan success rate. Tugas yang dapat diselesaikan oleh pengguna dengan benar adalah data yang digunakan untuk mengukur learnability.[18] Succes rate adalah presentase tugas yang dilakukan oleh pengguna dengan benar.[19] Berikut adalah rumus Succes rate:

Success Rate $=$

$\frac{\text { Swccess task }+(\text { partial success } x 0.5)}{\text { Total task }} \times 100 \%$

\section{e. Error}

Error terkait dengan kesalahan yang dibuat oleh pengguna, dapat segera dipulihkan oleh sistem. Defective rate digunakan untuk mengukur tingkat kesalahan yang dilakukan pengguna pada saat pengujian. Total defect merupakan total kesalahan yang dilakukan pada setiap tugas. Opportunities merupakan peluang kesempatan tugas. Sedangkan total participant merupakan jumlah pengguna yang melakukan pengujian.[20] Persamaannya dapat ditulis sebagai berikut :

$$
\begin{aligned}
& \text { Defective rate }=\frac{\text { Total Defects }}{\text { Total Opportunities }} \\
& =\frac{\text { Total Defects }}{\text { (Opportunities } x \text { Total participant) }}
\end{aligned}
$$

\section{f. Cognitive Load}

Cognitive load adalah beban kognitif yang diterima pengguna saat berinteraksi dengan aplikasi mobile. Cognitive load diukur dengan membandingkan jumlah keluhan, jumlah tugas yang yang selesai, jumlah klik, durasi waktu pengerjaan, jumlah kesalahan, durasi waktu permintaan waktu bantu dan durasi waktu bantu yang digunakan pengguna untuk mencari bantuan pada aplikasi terkait saat pengujian usability aplikasi mobile pada pengguna mahir dan pemula.[18] Kemudian data-data tersebut diolah menggunakan uji statistik Independent T- Test.

\section{g. Kuesioner SUS}

Kuesioner system usability scale (SUS) merupakan kuesioner usability yang digunakan untuk mengukur tingkat kepuasan pengguna terhadap suatu aplikasi. Data yang dikumpulkan dari pengguna menggunakan kuesioner SUS dapat dihitung dengan :

Untuk pertanyaan dengan nomor ganjil $(1,3,5,7,9)$ skor yang diberikan responden dikurangi 1.

skor SUS ganjil $=\sum \mathrm{Px}-1$
Untuk pertanyaan dengan nomor genap $(2,4,6,8,10)$ skor yang diberikan responden digunakan untuk mengurangi 5 .

skor SUS genap $=5-\sum \mathrm{Px}$

Setelah itu jumlahkan hasil dari setiap pertanyaan masing-masing responden lalu bagi 2.5

$\left(\sum\right.$ skor ganjil $+\sum$ skor genap $)$ x 2,5

Terakhir rata-ratakan hasil dari semua responden. Jumlahkan semua hasil score kemudian bagi dengan jumlah responden.

$\mathrm{X}^{-}=\sum \mathrm{x} \mathrm{n}$

Hasilnya berupa skor dengan rentang 0-100. SUS tidak bersifat diagnostik dan tidak akan memberi tahu masalah khusus apa yang ada dalam sistem, tetapi untuk mengetahui seberapa baik usability suatu sistem.[21] Skor SUS minimal untuk usability yang baik adalah sebesar 68.[16]

h. Kuesioner NASA-TLX

Beban kognitif atau cognitive load juga dapat diukur secara subjektif menggunakan kuesioner NASA-TLX. Ada 6 aspek yang diukur yaitu mental demand, physical demand, temporal demand, performance, effort, frustration. Setelah data rating dan bobot terkumpul dari semua responden kemudian dihitung menggunakan rumus yang ada. Beban Kerja Mental masingmasing responden berdasarkan NASA-TLX dihitung dengan persamaan berikut:

$=\left(\sum(\right.$ bobot $\mathrm{x}$ rating $\left.)\right) / 15$

Persamaan diatas digunakan untuk mengitung keenam variabel pengukuran dalam NASA-TLX. Kemudian hitung rata-rata beban kerja mental responden untuk mendapatkan hasil akhir

$=\left(\sum\right.$ beban kerja mental masing-masing responden $) /($ Jumlah Responden)

\section{...(11)}

Berdasarkan penjelasan Hart dan Staveland dalam teori Nasa-TLX, skor beban kerja yang diperoleh dapat diintepretasikan sebagai berikut [22] :

$\checkmark$ Nilai Skor > 80 menyatakan beban pekerjaan berat

$\checkmark$ Nilai Skor 50 - 70 menyatakan beban pekerjaan sedang

$\checkmark$ Nilai Skor < 50 menyatakan beban pekerjaan agak ringan

- Data Kualitatif

Data Kualitatif adalah data yang didapat dari teknik RTA berupa video yang memuat data verbal responden, data rekaman dari setiap responden tersebut diputar ulang kemudian mengubahnya dalam bentuk data tertulis dan visual. Data hasil proses rekaman tersebut akan 
disajikan dalam bentuk kesimpulan think aloud dari responden pada usability testing.

\section{HASIL DAN PEMBAHASAN}

\section{Effectiveness}

Hasil pengukuran effectiveness pada masingmasing task.

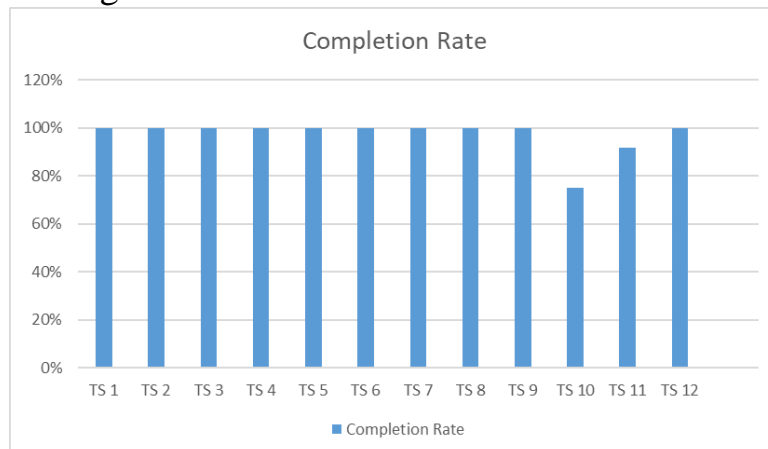

Gambar. 3 Diagram Hasil Completion Rate

Setelah dihitung rata-rata hasil completion rate keseluruhan task maka didapatkan nilai completion rate sebesar $97 \%$ sehingga sudah lebih tinggi dari rata-rata penyelesaian tugas minimum pada pengujian usability sebesar $78 \%$. Maka aplikasi Tabanan Dalam Gengaman sudah efektif.

2. Efficiency

\section{A. Time Based Efficiency}

Time based efficiency dihitung berdasarkan data durasi pengerjaan task skenario oleh responden didapatkan dari analisis video rekaman proses pengujian/ screen recorder lalu diubah menjadi satuan detik (seconds). Perhitungan time based efficiency untuk task 1

TBE TS1 $=\left(\frac{1}{8}+\frac{1}{93}+\frac{1}{111}+\frac{1}{191}+\frac{1}{70}+\frac{1}{84}+\frac{1}{154}+\right.$ $\left.\frac{1}{110}+\frac{1}{208}+\frac{1}{102}+\frac{1}{200}+\frac{1}{95}\right) /(1 * 12)$

$=0,01849251$

Sehingga setelah dihitung semua pengerjaan task dari semua responden didapatkan hasil sebagai berikut

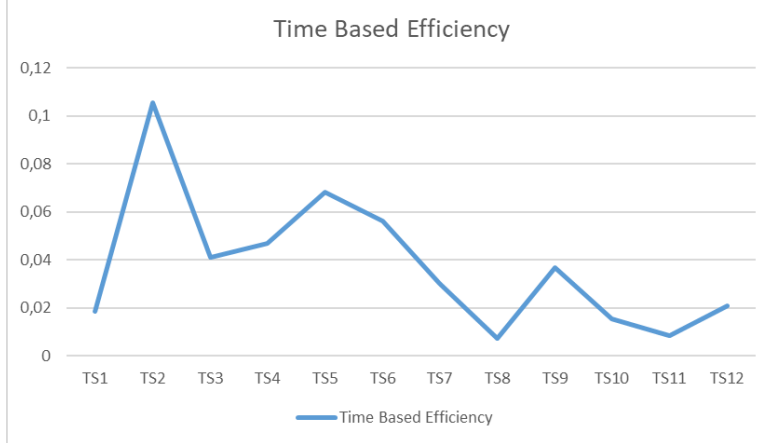

Gambar. 4 Diagram hasil time based efficiency

Berdasarkan rata-rata time based efficiency tingkat kecepatan penggunaan aplikasi per detiknya berdasarkan perhitungan time based efficiency didapatkan rata-rata hasil sebesar $0,0380050295 \mathrm{goal} / \mathrm{sec}$.

\section{B. Mann Whiteney U Test}

Pada pengujian statistik yang dilakukan diawali dengan menetapkan hipotesis untuk setiap task yang akan diuji. Adapun hipotesis yang peneliti gunakan untuk task $1 \mathrm{~s} / \mathrm{d} 12$ yaitu:

H0 : Tidak ada perbedaan waktu pengerjaan task (tugas) pada kelompok responden mahir dan kelompok responden pemula.

H1 : Ada perbedaan waktu pengerjaan task (tugas)pada kelompok responden mahir dan kelompok responden pemula.

Berikut adalah hasil uji statistik Mann Whiteney U Test :

Tabel. 2 Hasil Uji Statistic Mann Whiteney U Test

\begin{tabular}{lc}
\hline \multicolumn{1}{c}{ Task } & Mann Whiteney U Test \\
\cline { 2 - 2 } & Hasil \\
\hline TS1 & 0,078 \\
\hline TS2 & 0,631 \\
\hline TS3 & 0,150 \\
\hline TS4 & 0,199 \\
\hline TS5 & 0,065 \\
\hline TS6 & 0,148 \\
\hline TS7 & 0,378 \\
\hline TS8 & 0,055 \\
\hline TS9 & 0,054 \\
\hline TS10 & 0,628 \\
\hline TS11 & 0,336 \\
\hline TS12 & 0,377 \\
\hline
\end{tabular}

Berdasarkan data pada Tabel.4 dapat dilihat bahwa nilai p-value untuk task $1,2,3,4,5,6,7,8,10,11$ dan 12 lebih besar dari nilai $\alpha(0.05)$ maka kesebelas tugas tersebut memiliki keputusan tidak menolak H0. Sedangkan untuk task 9 nilai 0.054 atau sama dengan nilai $\alpha$ atau 0.05 maka tugas 9 memiliki keputusan $\mathrm{H} 1$ diterima.

Berarti dapat disimpulkan bahwa ada perbedaan yang signifikan secara statistik waktu pengerjaan tugas 9 untuk kelompok responden mahir dan responden pemula. Secara keseluruan dapat disimpulkan bahwa tidak ada perbedaan yang signifikan secara statistik waktu pengerjaan 11 tugas dan ada perbedaan yang signifikan secara statistik waktu pengerjaan tugas 9 untuk kelompok responden mahir dan responden pemula. Dari kesimpulan uji statistik tersebut dapat diputuskan bahwa aplikasi Tabanan Dalam Genggaman sudah efisien. 


\section{Memorability}

Data durasi pengerjaan task skenario oleh responden didapatkan dari analisis video rekaman proses pengujian/screen recorder lalu data durasi waktu pengerjaan task dapat Untuk menghitung overall relative efficiency data harus dikonversi kedalam satuan detik (seconds).

Adapun perhitungan overall relative efficiency untuk task 1

$\mathrm{TS} 1=$

$(((1 * 8)+(1 * 93)+(1 * 111)+(1 * 191)+(1 * 70)+(1 * 84$ )$+(1 * 154)+(1 * 110)+(1 * 208)+(1 * 102)+(1 * 200)+($ $1 * 95)) /(8+93+111+191+70+84+154+110+208+1$ $02+200+95))^{*} 100 \%=100 \%$

Setelah dihitung dengan overall relative efficiency semua task dari semua responden didapatkan hasil sebagai berikut :

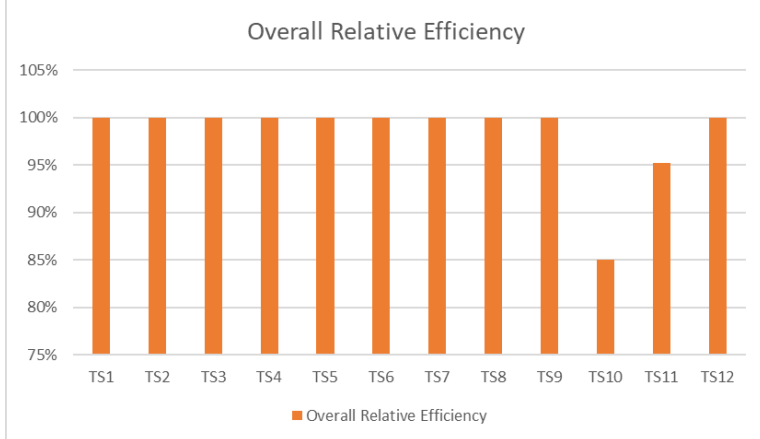

Gambar. 5 Diagram hasil overall relative efficiency

Setelah dihitung rata-rata hasil overall relative efficiency keseluruhan task maka didapatkan nilai completion rate sebesar 98\%. Memorability dapat dihitung dari kombinasi nilai effectiveness dan overall relative efficiency.[17] Sehingga berdasarkan rata-rata hasil overall relative efficiency yang didapat sebesar $98 \%$ dan nilai rata-rata effectiveness sebesar 97\%. Sesuai dengan hasil tersebut aplikasi Tabanan Dalam Genggaman dapat dikategorikan sangat memorable (sangat mudah diingat).

\section{Learnability}

Learnability diukur berdasarkan data performance measurement yaitu berdasarkan jumlah tugas yang dilakukan dengan benar oleh responden. Kemudian data dihitung dengan rumus success rate.

Rekap Data Pengerjaan Task Jumlah total task utama $\quad: 12$ Jumlah total subtask $\quad: 144$ Total success task (S) $\quad: 126$ Total partial success $(\mathrm{P}) \quad: 14$ Total failed (F) $: 4$
Success Rate $=\frac{126+(14 \times 0.5)}{144} \times 100 \%=92 \%$

Hasil perhitungan success rate untuk mengukur komponen learnability didapatkan sebesar 92\%. Dari hasil tersebut dapat disimpulkan bahwa aplikasi Tabanan Dalam Genggaman sangat mudah dipelajari.

\section{Error}

Berikut ini adalah perhitungan Defective rate untuk task 1

Defective Rate $\operatorname{TS} 1=\frac{7}{48}=0,145833$

Sehingga setelah dihitung semua defective rate dari semua task tiap responden didapatkan hasil sebagai berikut :

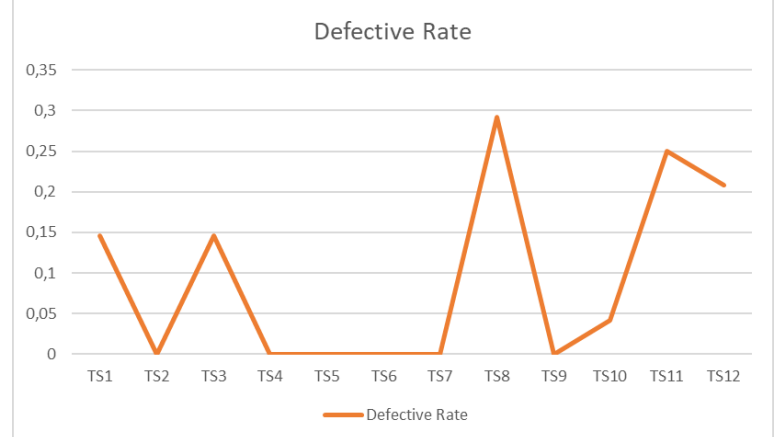

Gambar. 6 Diagram Hasil Defective Rate

Rata-rata kesalahan tiap tugas adalah 0.7.[23] Sehingga jika dibandingkan dengan hasil defective rate kedua belas task dapat ditarik kesimpulan bahwa tingkat kesalahan dan penyebab kesalahan ada aplikasi Tabanan Dalam Genggaman masih dalam kategori wajar.

\section{Cognitive Load}

a. Independent T Test

Data cognitive load diolah menggunakan software SPSS menggunakan uji statistik independent $t$ test. Karena independent $t$ test termasuk pada kategori statistik parametrik maka sebelumnya harus dilakukan uji normalitas dan homogenitas terhadap data yang akan diolah.

Dari output uji normalitas dengan SPSS didapakan bahwa hasil uji normalitas data cognitive load untuk responden mahir sebesar ,346 sedangkan responden pemula sebesar,882. Sehingga data cognitive load dari responden mahir dan responden pemula adalah berdistribusi normal. Setelah mengetahui data berdistribusi normal dan homogen maka dapat dilanjutkan untuk melakukan uji statistik independent $t$ test. Hipotesis untuk uji independent $\mathrm{t}$ test

H0 : Tidak ada perbedaan beban cognitive berdasarkan data performance padakelompok

Perhitungan : 
responden mahir dan kelompok responden pemula.

H1 : Ada perbedaan beban cognitive berdasarkan data performance padakelompok responden mahir dan kelompok responden pemula.

Untuk data hasil uji statistik independent $\mathrm{t}$ test cognitive load didapatkan hasil $p$-value sebesar ,010 lebih kecil $(<)$ dari 0.05. Sehingga keputusan yang diambil dari pengolahan data tersebut adalah menerima H1. Berarti dapat disimpulkan bahwa ada perbedaan yang signifikan secara statistik pada beban cognitive berdasarkan data performance untuk kelompok responden mahir dan responden pemula.

b. Kuesioner NASA-TLX

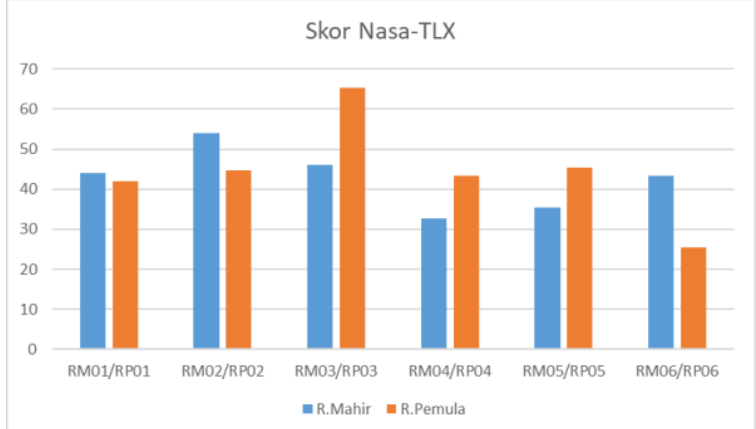

Gambar. 7 Diagram Skor NASA-TLX

Rata-rata hasil cognitive load dengan kuesioner NASA-TLX seluruh responden adalah sebesar 43,4444. Hasil yang didapat lebih kecil dari 50 sehingga dapat dikatakan bahwa beban cognitive yang dialami pengguna saat menggunakan aplikasi Tabanan Dalam Genggaman agak ringan.

\section{Satisfaction}

Tingkat kepuasan pengguna diukur dengan menggunakan kuesioner SUS ( System Usability Scale).

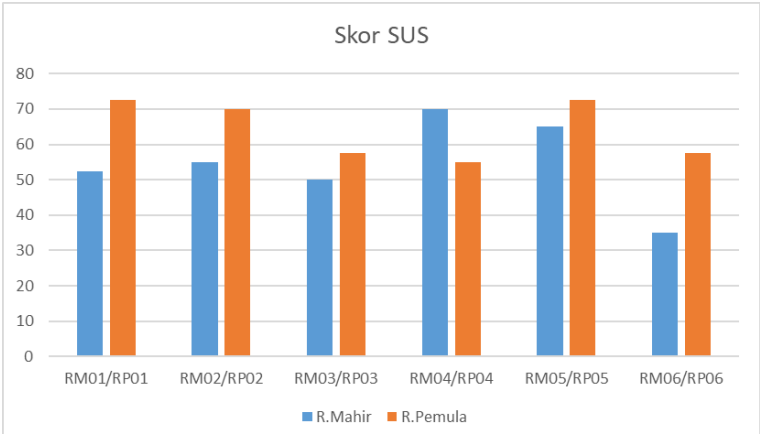

Gambar. 8 Skor SUS

Berdasarkan perhitungan didapatkan bahwa rata-rata hasil kuesioner SUS keseluruhan responden adalah sebesar 59,375. Hasil yang didapat lebih kecil dari skor minimal SUS yaitu sebesar 68. Namun ada pada status marginal pada acceptability ranges dan dalam status good pada untuk adjective rating. Sehingga dapat dikatakan bahwa aplikasi Tabanan Dalam Genggaman memiliki tingkat usability yang baik dengan status penerimaan pada kategori marginal. Sehingga pengguna merasa puas saat menggunakan aplikasi Tabanan Dalam Genggaman jika mengacu pada hasil analisis kuesioner SUS dengan range penerimaan ada pada kategori marginal (tengah) adjective rating (rating yang dideskripsikan dengan kata sifat) pada kateori good (baik).

\section{Rekomendasi Perbaikan}

Setelah melakukan pengujian usability dan mengolah data hasil pengujian aplikasi Tabanan Dalam Genggaman dapat dikategorikan telah memenuhi tingkat usability yang baik untuk sebuah aplikasi mobile.

Sehingga untuk lebih meningkatkan lagi usability pada aplikasi Tabanan Dalam Genggaman peneliti merancang rekomendasi perbaikan berdasarkan data performance measurement dan RTA. Rekomendasi dirancang dalam bentuk wireframe/mockup yang didasarkan pada teori 8 golden rules dari Benn Sneidermann dan 10 prinsip user interface aplikasi mobile dari Jonathan Stark

a. Halaman Daftar/Login

Berdasarkan analisis dengan teori 8 golden rules, hal ini belum memenuhi poin kedua yaitu cater to univer usability (memenuhi kegunaan yang universal) dan poin delapan yaitu reduce short-term memory load. Sehingga rekomendasi perbaikan yang dapat diajukan adalah dengan membuat halaman login/daftar dengan menyediakan satu button saja yaitu button masuk dan menghilangkan button daftar. Namun menyediakan link menuju ke halaman daftar akun dibagian bawah.

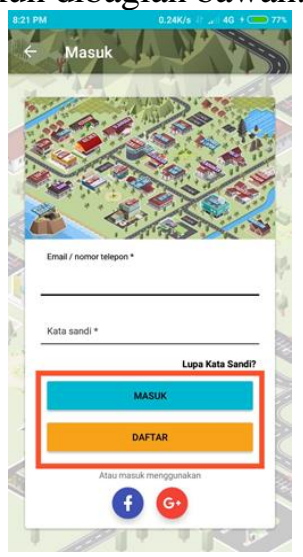

Sebelum

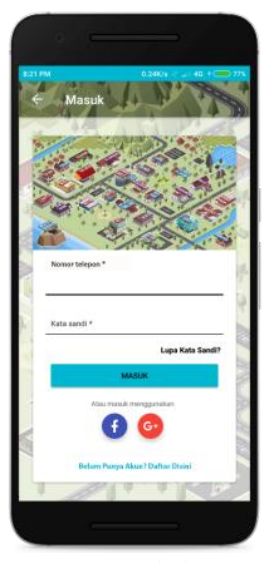

Sesudah
Gambar. 9 Rekomendasi perbaikan halaman $\operatorname{login}$ 
b. Alert

Warna merah identik dengan fatal error (danger). Sehingga dapat memicu kepanikan pada responden yang tidak terlalu paham. Berdasarkan 10 prinsip user interface aplikasi mobile hal ini tidak sesuai dengan poin 8 (Modal alert) sehingga rekomendasi perbaikan yang diberikan yaitu mengganti alert menjadi warna orange/kuning yang menandakan sebuah warning (peringatan) agar lebih berhati-hati. Serta dapat hilang otomatis setelah beberapa saat. Berikut adalah tampilan sebelum dan sesudah :

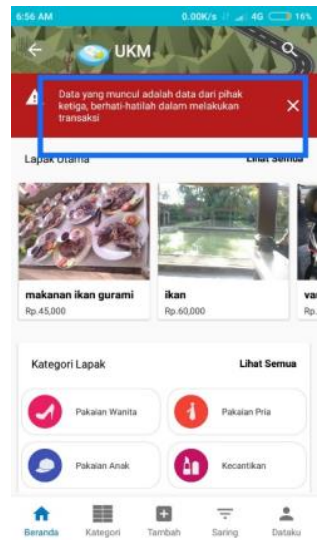

Sebelum

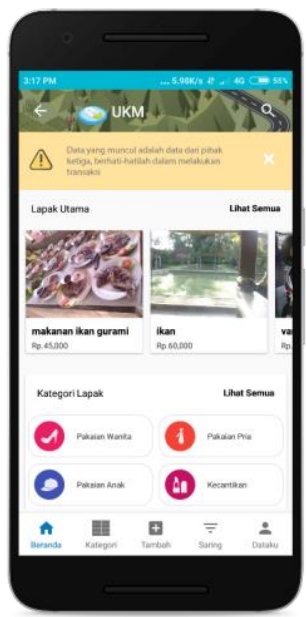

Sesudah
Gambar. 10 Rekomendasi perbaikan alert

\section{c. Menu Utama}

Berdasarkan 10 prinsip user interface aplikasi mobile pada poin 1 mindset (be focused), poin 2 context (bored). Direkomendasikan perbaikan agar menu utama lebih teratur, interaktif, dan userfriendly. Berikut adalah tampilan sebelum dan sesudah :

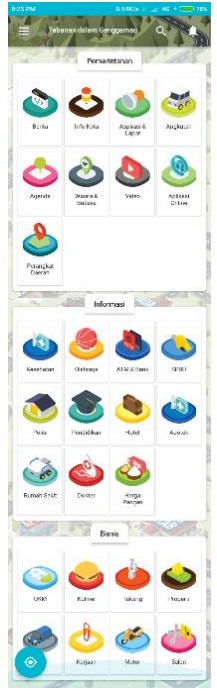

Sebelum

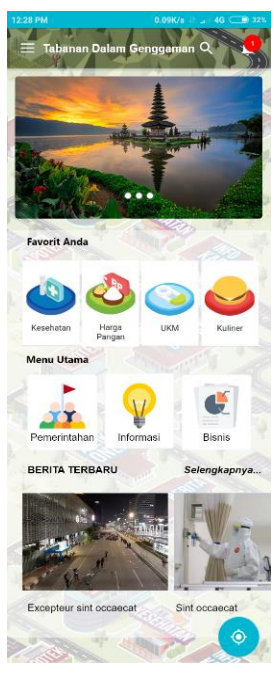

Sesudah
Gambar. 11 Rekomendasi perbaikan menu utama d. Edit data

Berdasarkan 10 prinsip user interface aplikasi mobile poin 3 guidliness (content dan targets) maka dibuat sebuah rekomendasi perbaikan yaitu mengganti button opsi karena pilihan opsinya hanya 1 yaitu edit. Kemudian diganti dengan button edit agar lebih terlihat. Berikut adalah tampilan sebelum dan sesudah :

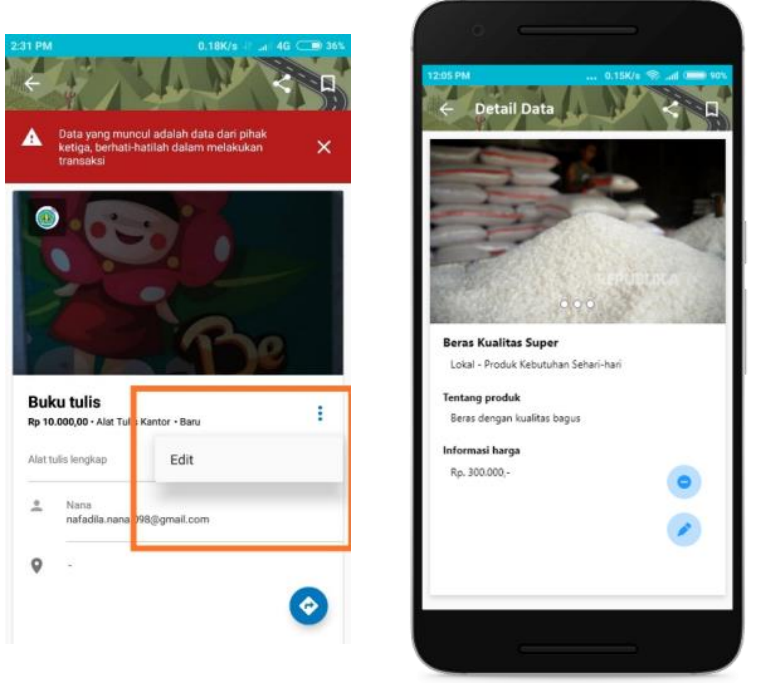

Gambar. 12 Rekomendasi perbaikan halaman edit

\section{KESIMPULAN}

Setelah melakukan penelitian usability testing menggunakan model PACMAD pada aplikasi Tabanan Dalam Genggaman dengan metode performance measurement, RTA (Retrospective think aloud), kuesioner SUS (System Usability Scale) dan kuesioner NASA-TLX. Berdasarkan pada hasil yang didapat maka aplikasi Tabanan Dalam Genggaman dapat dikategorikan telah memenuhi tingkat usability yang baik untuk sebuah aplikasi mobile. Hal ini berdasarkan pada 7 atribut usability pada model PACMAD yaitu efficiency sebesar 0,0380050295 goals/second, effectiveness 97\%, learnability 92\%, memorability $98 \%$, error 0,090278 , satisfaction 59,375 dan cognitive load 43,4444. Sebagai upaya meningkatkan usability pada aplikasi Tabanan Dalam Genggaman maka dirancangan rekomendasi perbaikan dalam bentuk wireframelmockup yang didasarkan pada teori 8 golden rules dari Benn Sneidermann dan 10 prinsip user interface aplikasi mobile dari Stark,J. Hasil analisis data performance measurement dan data hasil RTA dijadikan sebagai acuan dan pertimbangan untuk memutuskan bagian, halaman, dan fitur dalam aplikasi Tabanan Dalam Genggaman yang akan 
diberikan rekomendasi perbaikan.

Halaman login/daftar dan menu utama adalah halaman yang mendapat rekomendasi perbaaikan karena halaman tersebut banyak terjadi kegagalan dan kesalahan saat mengerjakan task scenario (performance measurement) dan yang paling dominan mendapat sorotan terkendala saat pengerjaan atau keluhan yang disampaikan responden pada saat wawancara RTA.

\section{DAFTAR PUSTAKA}

[1] J. Nielsen, Usability Engineering. USA: United States of America: Academic Press, 1993.

[2] S. Lestari, "Analisis Usability Web ( Studi Kasus Website Umkm Binaan Bppku Kadin Kota Bandung )," J. Ilm. Teknol. Inf. Terap., vol. 1, no. 1, p. (halaman 46), 2014.

[3] R. Harrison, D. Flood, and D. Duce, "Usability of mobile applications: literature review and rationale for a new usability model," J. Interact. Sci., vol. 1, no. 1, p. 1, 2013, doi: 10.1186/2194-0827-1-1.

[4] Utama, "Perbaikan User Interface Halaman Internet Banking Dengan Metode Usability Testing," Universitas Indonesia, 2011.

[5] A. Sriwulandari, H. Hidayati, and B. Pudjoatmojo, "Analisis dan Evaluasi Aspek Usability Pada Web HRMIS Telkom University Menggunakan Usability Testing Analysis and Evaluation of Usability Aspects on Web HRMIS Telkom University Using Usability Testing," in e-Proceeding of Engineering, 2014, vol. 1, no. 1, pp. 537-542.

[6] M. I. Farouqi, I. Aknuranda, and A. D. Herlambang, "Evaluasi Usability pada Aplikasi Go-Jek Dengan Menggunakan Metode Pengujian Usability," J. Pengemb. Teknol. Inf. dan Ilmu Komput., vol. 2, no. 10, pp. 3150-3156, 2018, [Online]. Available: http://j-ptiik.ub.ac.id/index.php/jptiik/article/download/2396/947/.

[7] G. Wernaart, Cognitive Load Measurement: Different instruments for different types of load? Netherland: Master Onderwijskundig Ontwerp en Advisering Universiteit Utrecht, 2012.

[8] W. A. Pramono, H. M. Az-Zahra, and R. I. Rokhmawati, "Evaluasi Usability pada Aplikasi MyTelkomsel dengan Menggunakan Metode Usability Testing," Pengemb. Teknol. Inf. dan Ilmu Komput., vol. 3, no. 3, pp. 2235 2242, 2019.

[9] J. Nielsen, "Turn User Goals into Task Scenarios for Usability Testing,” 2014. https://www.nngroup.com/articles/taskscenarios-usability-testing/ (accessed Feb. 07, 2020).
[10] A. M. Ersa, "Usability Evaluation Website EGovernment Layanan Aspirasi dan Pengaduan Online (LAPOR!)," Skripsi, 2015.

[11] J. Brooke, "SUS: A Retrospective John," $J$. usability Stud., vol. 8, no. 2, pp. 29-40, 2013.

[12] R. Alturki and V. Gay, "Usability Testing of Fitness Mobile Application : Methodology and Quantitative Results," Comput. Sci. Inf. Technol. (CS IT), no. September, pp. 97-114, 2017, doi: 10.5121/csit.2017.71108.

[13] A. M. Yusuf, Metode Penelitian: Kuantitatif, Kualitatif, Dan Penelitian Gabungan. Jakarta: Jakarta: Kencana, 2014.

[14] J. Nielsen, "Why You Only Need to Test with $5 \quad$ Users," 2000. https://www.nngroup.com/articles/why-youonly-need-to-test-with-5-users/ (accessed Feb. 07, 2020).

[15] C. Gatsou, A. Politis, and D. Zevgolis, "Exploring inexperienced user performance of a mobile tablet application through usability testing.," 2013 Fed. Conf. Comput. Sci. Inf. Syst. FedCSIS 2013, pp. 557-564, 2013.

[16] J. Mifsud, "Usability Metrics - A Guide To Quantify The Usability Of Any System," 2011. https://usabilitygeek.com/usabilitymetrics-a-guide-to-quantify-system-usability/ (accessed Feb. 07, 2020).

[17] N. Fauzi, H. M. Az-zahra, and A. P. Kharisma, "Analisis Usability Aplikasi Perangkat Bergerak Jual Beli Online dengan Model People At The Center of Mobile Application Development ( PACMAD ) ( Studi Kasus: Tokopedia , Bukalapak dan Shopee )," J. Pengemb. Teknol. Inf. dan Ilmu Komput., vol. 3, no. 3, pp. 2552-2557, 2019.

[18] R. Rizawanti, I. K. R. Arthana, and P. W. A. Suyasa, "Usability Testing Pada Aplikasi Hooki Arisan Dengan Model Pacmad Menggunakan Pendekatan Gqm," Kumpul. Artik. Mhs. Pendidik. Tek. Inform., vol. 8, no. 1, p. 33, 2019, doi: 10.23887/karmapati.v8i1.16983.

[19] J. Nielsen, "Success Rate: The Simplest Usability Metric," 2001. https://www.nngroup.com/articles/successrate-the-simplest-usability-metric/ (accessed Feb. 07, 2020).

[20] A. D. Listikowati, I. Aknuranda, and A. R. Perdanakusuma, "Evaluasi Usability Situs Web Sistem Informasi Perencanaan Pembangunan Daerah (SIPPD) v3.0 menggunakan Metode Usability Testing (Studi Kasus : Bappelitbangda Kota Batu)," J. Pengemb. Teknol. Inf. dan Ilmu Komput., vol. 3, no. 5, pp. 4777-4786, 2019.

[21] N. Thomas, "How To Use The System Usability Scale (SUS) To Evaluate The Usability Of Your Website," 2011. https://usabilitygeek.com/how-to-use-the- 
system-usability-scale-sus-to-evaluate-theusability-of-your-website/ (accessed Feb. 07, 2020).

[22] B. Hendrawan, M. Ansori, and R. Hidayat, "Pengukuran dan Analisis Beban Kerja Pegawai Bandara Hang Nadim Jurusan Manajemen Bisnis Politeknik Negeri Batam," J. Akuntansi, Ekon. dan Manaj. Bisnis, vol. 3, no. 1, pp. 55-67, 2013.

[23] J. Sauro, "Measuring Errors in the User Experience," 2012. https://measuringu.com/errors-ux/ (accessed Feb. 07, 2020). 